Bulatović Petar*

UDK: 351.74

Review article

DOI: $10.5937 /$ ptp2101055B

Received: February 10th 2021

Approved on: February 24th 2021

Pages: 55-69

\title{
THE PERFORMANCE OF POLICE DUTIES \\ IN THE CONTEXT OF THE PRINCIPLES \\ GOVERNING THE OPERATION OF THE STATE ADMINISTRATIVE AUTHORITIES
}

\begin{abstract}
Police duties represent a part of the internal affairs performed by the Police, by applying the police authority, measures and actions. The new concept of combating crime is based on the preventive activities of the police and judiciary. In this sense, the police affairs can be approached from different aspects. The primary role of the police is in the criminal and misdemeanor procedure, but, as it can be concluded in the text of this paper, the administrative activities of the police in preventing, detecting, and solving criminal acts, misdemeanors, and other crimes are also very important. So, the paper deals with the issues that significantly helped the main topic of this research paper to be analyzed in the best possible way. This paper analyzes the issues related to the affairs of the Ministry of Internal Affairs, the organization and competence of the police, the principles of operation of the state administrative bodies, police affairs and criminal and misdemeanor procedure as well as administrative activities of the police in preventing, detecting and solving crimes and other offenses. The primary legal texts being consulted were the Law on Police and the Law on State Administration, in addition to consulting two important Rulebooks in this area - the Rulebook on police powers and the Rulebook on the manner of performing individual police duties.
\end{abstract}

Keywords: Police Duties, State Administrative Authorities, Principles, Criminal Procedure Activities Concerning Police, Administrative Duties of the Police

\footnotetext{
${ }^{*}$ LLM, Belgrade Business and Arts Academy of Applied Studies, Serbia, e-mail: petar.bulatovic.011@gmail.com
} 


\section{Introduction}

Administrative bodies have powers based on legal norms (objective law), with any discretionary activity being allowed very restrictively. In that sense, discretionary assessment and actions of administrative bodies are not absolutely exempt, nor is it considered that the administration should mechanically and strictly enforce the provisions of the law, but extremely restrictively and for reasons of expediency, the administration can be entrusted with some discretionary powers. It is explicitly stated that the administrative bodies exercise their powers in the interest of society. According to Vasiljević (2012), "in a state governed by the rule of law, the administration is law-bound, and it is only in extreme cases a free activity" (p. 20).

According to article 30, Paragraph 1 of the Law on Police "Police duties are part of internal affairs duties that are performed by the Police by way of applying police measures and actions and exercising police powers" (Law on Police, 2016). In this context, Jugović (2009) points out that "police activity is characterized by the intertwining of police and other tasks and powers in accordance with the scope and competencies. Police and other jobs and tasks are intertwined with the application of certain police and other powers, all with the aim of protecting security, human rights and performing internal affairs" (pp. 191-192). Analyzing the development of the police organization, from the traditional concept to the modern - Community policing concept, Simić and Nikač (2009) state that "the police should be: a service (efficient, effective and high-quality) and not a just force, accountable to the law and the public, transparent and recognizable, professional, people-oriented, visible and accessible, advisory and involved in the community, an organization that responds in a timely manner and acts preventively "(p. 129). Jovanović (2016) also states that "current reforms promote the view that the police is a service to citizens and a public service in the function of a safer communities, respect and protection of the right to life, physical integrity and freedom of citizens" (p. 138), and that "implementation of requirements for the improvement of the professional work of the police, the lawful application of regulations, special police powers and means of coercion" (Jovanović, 2016, p. 138) is actually the result of our country's determination to become a member of the European Union. 


\section{Activity of the Ministry of Internal Affairs, Organization and Competencies of the Police}

Article 1 of the Law on State Administration promulgates that the state administration is a part of the executive power of the Republic of Serbia performing administrative tasks from the framework of the rights and obligations of the Republic of Serbia, and it includes ministries, administrative authorities within the ministries and special organizations (Law on State Administration 2005). Article 2 of the Law on Police stipulates that internal affairs are „, a public administration function stipulated by law, performed by the Ministry, committed to achieving and improving the safety of citizens and property, upholding the rule of law and ensuring the exercise of human and minority rights and freedoms laid down by the Constitution and statutory provisions, as well as other related tasks within the established purview and competence of the Ministry (Law on Police, 2016). Ministry of Internal affairs, according to the provisions of the Law on Ministries ,performs state administration tasks related to: protection of life, protection of life, safety and property of citizens;; prevention and detection of criminal offenses and finding and apprehending the perpetrators of criminal offenses and bringing them to the competent authorities; maintenance of public order and peace; providing emergency assistance; shelters; providing the right to asembly and other gatherings of citizens; securing certain persons and facilities, including foreign diplomatic and consular missions on the territory of the Republic of Serbia; road safety, regulation and control; proposing acts related to the exercise of founding rights over the public agency responsible for traffic safety; security of the state border and control of border crossings and movement and stay in the border zone; stay of foreigners; trade and transport of weapons, ammunition, explosives and certain other dangerous substances; testing of small arms, devices and ammunition; creating conditions for access and implementation of projects within the scope of that ministry which are financed from the funds of the pre-accession funds of the European Union, donations and other forms of development assistance; fire protection; citizenship; identification number; electronic management of personal data; residence and stay of citizens; ID cards; travel documents; international assistance and other forms of international cooperation in the field of internal affairs, including readmission; illegal migration; asylum; staff training; administrative resolution in the second instance procedure on the basis of regulations on refugees, as well as other tasks determined by law "(Law on Ministries, 2020, art. 13). 
Law on Police stipulates that „For performing police and other internal duties, the Police Directorate shall be established and headed by the Police Director. The Police Directorate shall comprise organizational units within its headquarters-departments, centers, units, the special unit and specialized police units, and outside its headquarters-the City of Belgrade Police Department, regional police departments, and police stations" (Law on Police, 2016, art. 22-23). Milić (2010) points out that "a police precinct is formed in the area of a police station, with or without police departments. The area of the police precinct is a part of the space where police officers of general competence perform specific tasks and activities within their competence, which is manifested in the form of action or activities of the police organization and undertaking of various measures and actions to ensure greater security in the local area" (p. 117). According to Milidragović and Milić (2019), "the organizational structure of the Police must be established to meet the security needs of the people and their property in the relevant areas, as well as to meet the obligation to act directly, concretely and urgently wherever there is a need for such action" (p. 64).

In addition to the organization, an important issue in this topic that is related to the Police ${ }^{1}$ is certainly the issue of police competencies. We can distinguish the following competencies of the police: the affairs of the Police Directorate, the affairs of the Police Department, and the affairs of the Police Station. Table 1 explains the stated competencies of the Police. Before the table of competencies, we should mention the issues that are also relevant in this part, namely the role of the Police in the community, the actions of the Police in the case of domestic violence, as well as the actions of the Police in a state of increased risk. Article 27 of the Law on Police stipulates that "The Police shall develop cooperation and partnership with citizens and other municipal entities with the view to performing policing duties and addressing local security priorities, and shall coordinate common interests and the need to create a favorable security environment in the community, namely to build a safe democratic society." The same law stipulates that in the case of reporting domestic violence, or the threat of domestic violence, "police officers shall, in cooperation with other competent authorities, immediately take the necessary measures and actions in accordance with the law, to prevent or stop the violence which may result in the

\footnotetext{
${ }^{1}$ In this part, it is important to clarify what police is. So, the police, in terms of the Law on Police, represents "the central organizational unit of the Ministry, which in the performance of interior, i.e. police duties, protects and improves the safetyof citizens and property, abiding by the Constitutionally guaranteed human and minority rights and freedoms and other protected values in a democratic society, with a possibility of using the means of coercion set out in the Constitution and law" (Law on Police, 2016, art. 3).
} 
infliction of bodily injuries or deprivation of life" (Law on Police, 2016, art. 28). Furthermore, ,If circumstances or events indicate that public security may become exposed to increased risk and that human and property security may be jeopardized to a greater extent, which would require partial or full readiness of police officers and engagement of all technical resources and equipment in a part of the territory of the Republic of Serbia, the Minister shall, at the proposal of the Police Director, issue the order for carrying out tasks corresponding to the circumstances" (Law on Police, 2016, art. 29).

Table 1. Activities of the Police Directorate, Police Department, and Police Station

\begin{tabular}{|c|c|c|}
\hline $\begin{array}{c}\text { Activities of the Police } \\
\text { Directorate }\end{array}$ & $\begin{array}{c}\text { Activities of the Police } \\
\text { Department }\end{array}$ & $\begin{array}{c}\text { Activities of the Police } \\
\text { Station }\end{array}$ \\
\hline $\begin{array}{c}\text { Prepares a strategic } \\
\text { assessment of public } \\
\begin{array}{c}\text { safety, in cooperation with } \\
\text { the organizational unit } \\
\text { responsible for strategic } \\
\text { planning; }\end{array}\end{array}$ & $\begin{array}{c}\text { Directly performs policing and } \\
\text { other internal affairs tasks and } \\
\text { implement local cooperation, } \\
\text { in the territory of the } \\
\text { municipality, or town, where } \\
\text { its headquarters are located }\end{array}$ \\
$\begin{array}{c}\text { directly perform } \\
\text { police duties and other } \\
\text { internal affairs tasks and } \\
\text { effectuate cooperation } \\
\text { in the territory of the } \\
\text { municipality for which it } \\
\text { was established, within } \\
\text { the police department. }\end{array}$ \\
$\begin{array}{c}\text { Adopts the strategic plan of } \\
\text { the Police }\end{array}$ & $\begin{array}{c}\text { Develops the operational } \\
\text { public security assessment }\end{array}$ & $\begin{array}{c}\text { The police station shall, } \\
\text { once a year, submit } \\
\text { the information on its } \\
\text { work and the security } \\
\text { situation to the municipal } \\
\text { assembly of the local } \\
\text { self-government in the } \\
\text { territory where it is } \\
\text { located. }\end{array}$ \\
\hline $\begin{array}{c}\text { Participates in the } \\
\text { development of the human } \\
\text { resources plan, as well } \\
\text { as in the development of } \\
\text { professional training and } \\
\text { capacity building programs } \\
\text { in cooperation with the } \\
\text { organizational unit in } \\
\text { charge of human resources } \\
\text { management }\end{array}$ & $\begin{array}{c}\text { Adopts the police department's } \\
\text { operational plan }\end{array}$ & \\
\hline
\end{tabular}




\begin{tabular}{|c|c|c|}
\hline $\begin{array}{c}\text { Activities of the Police } \\
\text { Directorate }\end{array}$ & $\begin{array}{c}\text { Activities of the Police } \\
\text { Department }\end{array}$ & $\begin{array}{c}\text { Activities of the Police } \\
\text { Station }\end{array}$ \\
\hline $\begin{array}{l}\text { Coordinates and guides the } \\
\text { work of police departments } \\
\text { and organizational units } \\
\text { within the headquarters }\end{array}$ & $\begin{array}{l}\text { Harmonizes, coordinates, } \\
\text { and guides the work of police } \\
\text { stations/field offices and } \\
\text { ensure the implementation } \\
\text { of local cooperation and } \\
\text { accountability }\end{array}$ & \\
\hline $\begin{array}{l}\text { Performs oversight and } \\
\text { instructional activity in the } \\
\text { work of police departments } \\
\text { and organizational units } \\
\text { within the headquarters }\end{array}$ & $\begin{array}{c}\text { Performs oversight and } \\
\text { instructional activity in the } \\
\text { work of its organizational units }\end{array}$ & \\
\hline $\begin{array}{l}\text { Participates directly in the } \\
\text { performance of certain } \\
\text { more complex tasks within } \\
\text { the purview of police } \\
\text { departments }\end{array}$ & $\begin{array}{l}\text { Participates, as necessary, } \\
\text { in the performance of tasks } \\
\text { within the police stations' } \\
\text { purview }\end{array}$ & \\
\hline $\begin{array}{l}\text { Ensures the implementation } \\
\text { of international police } \\
\text { cooperation agreements } \\
\text { and other international acts } \\
\text { within its purview }\end{array}$ & $\begin{array}{l}\text { Takes measures to safeguard } \\
\text { specific persons and facilities }\end{array}$ & \\
\hline $\begin{array}{c}\text { Performs activities relating } \\
\text { to international operational } \\
\text { police cooperation }\end{array}$ & $\begin{array}{c}\text { Provides regular and urgent } \\
\text { information and reporting to the } \\
\text { Police Directorate on occurrences } \\
\text { and events in its area; }\end{array}$ & \\
\hline $\begin{array}{l}\text { Creates the required } \\
\text { conditions for maintaining } \\
\text { and improving the } \\
\text { Police capabilities and } \\
\text { preparedness for acting } \\
\text { in situations of increased } \\
\text { risk, emergencies, states of } \\
\text { emergency, and war }\end{array}$ & $\begin{array}{l}\text { Submits, annually, the } \\
\text { information on its work and } \\
\text { the security situation to the } \\
\text { municipal assembly of the } \\
\text { local self-government in the } \\
\text { territory where it is located }\end{array}$ & \\
\hline $\begin{array}{l}\text { Carries out administrative } \\
\text { tasks relating to citizens' } \\
\text { status issues and issuance } \\
\text { of public documents within } \\
\text { its purview }\end{array}$ & $\begin{array}{l}\text { Performs other tasks defined } \\
\text { by special laws, other } \\
\text { regulations, and general acts }\end{array}$ & \\
\hline $\begin{array}{l}\text { Contributes to security- } \\
\text { police and educational- } \\
\text { instructional activities in } \\
\text { police work }\end{array}$ & & \\
\hline
\end{tabular}

Source: Police Law, 2016, art. 24-26. 


\section{Principles of Operation of the State Administrative Bodies}

According to Article 2 of the Law on State Administration, "state administration authorities are formed by law" (Law on State Administration, 2005). State administration authorities take care, in accordance with the Constitution, laws, and other acts, of the implementation of special measures in order to achieve full equality of persons and groups of persons who are essentially in an unequal position with other citizens (Kulić, 2017, p. 55). The same law determines and defines the principles of operation of state administration authorities, which are presented in the table below.

Table 2. Principles of Work of State Administration Authorities

\begin{tabular}{|l|l|l|l|}
\hline Number & Principle & $\begin{array}{l}\text { Article of } \\
\text { the Law }\end{array}$ & The legal definition of the Principle \\
\hline 1 & $\begin{array}{l}\text { Autonomy and } \\
\text { Legality }\end{array}$ & Article 7 & $\begin{array}{l}\text { State administration authorities shall } \\
\text { be autonomous in the execution of } \\
\text { their tasks and shall work within and in } \\
\text { accordance with the Constitution, law, } \\
\text { other legislation, and general acts. }\end{array}$ \\
\hline 2 & $\begin{array}{l}\text { Expertise, } \\
\text { Impartiality, and } \\
\text { Political Neutrality }\end{array}$ & Article 8 & $\begin{array}{l}\text { State administration authorities shall } \\
\text { act in accordance with the professional } \\
\text { rules, impartially and politically neutral } \\
\text { and they shall be obliged to provide for } \\
\text { everyone equal legal protection in the } \\
\text { exercise of rights, obligations, and legal } \\
\text { interests. }\end{array}$ \\
\hline 3 & $\begin{array}{l}\text { Efficiency in } \\
\text { Exercise of Parties } \\
\text { Rights }\end{array}$ & Article 9 & $\begin{array}{l}\text { State administration authorities shall be } \\
\text { obliged to enable the parties to promptly } \\
\text { and efficiently exercise their rights and } \\
\text { legal interests. }\end{array}$ \\
\hline 4 & $\begin{array}{l}\text { Proportionality. } \\
\text { Respect of Parties }\end{array}$ & Article 10 & $\begin{array}{l}\text { When deciding on administrative } \\
\text { procedure and undertaking administrative } \\
\text { actions, state administration authorities } \\
\text { shall be obliged to use means that are the } \\
\text { most favorable for a party, providing that } \\
\text { the means can achieve the purpose and } \\
\text { goal of the law. } \\
\text { State administration authorities shall be } \\
\text { obliged to respect the person and dignity } \\
\text { of parties. }\end{array}$ \\
\hline
\end{tabular}




\begin{tabular}{|l|l|l|l|}
\hline Number & Principle & $\begin{array}{l}\text { Article of } \\
\text { the Law }\end{array}$ & The legal definition of the Principle \\
\hline 5 & Publicity of Work & Article 11 & $\begin{array}{l}\text { The work of state administration } \\
\text { authorities shall be public. } \\
\text { State administration authorities shall } \\
\text { be obliged to enable the public to have } \\
\text { access to their work in accordance } \\
\text { with the law regulating free access to } \\
\text { information of public importance. }\end{array}$ \\
\hline
\end{tabular}

Source: Law on State Administration, 2005, art. 7-11

\section{Police Duties}

According to the provisions of the Law on Police "Police duties are part of internal affairs duties that are performed by the Police by way of applying police measures and actions and exercising police powers in order to achieve safety and protection of life, rights, and freedoms of citizens, protection of property, as well as to support the rule of law (Police Law, 2016, art. 30).

According to the provisions of the same article "Police duties include: 1) crime prevention and improvement of community safety; 2) detection and apprehension of perpetrators of criminal offenses and misdemeanors and other persons wanted by the police and bringing them before competent authorities, ensuring evidence, analyzing evidence, forensic expertise by using modern forensic methods and records; 3) detection and investigation of criminal offenses, misdemeanors and violations; 4) maintenance of public order, prevention of violence at sports events, provision of assistance in enforcements in accordance with special laws; 5) regulation, control, provision of assistance and supervision in road traffic, and other tasks set out in traffic safety regulations; 6) safeguarding of certain public gatherings, individuals, authorities, facilities and designated areas; 7) control of state borders, tasks relating to the movement and stay of foreigners, tasks related to asylum, cross-border crime, irregular migration and readmission; 8) performance of tasks set out in the regulations on weapons, private security and private investigation activity; 9) safeguarding the Ministry; 10) performance of other police duties and tasks established by law and secondary legislation adopted based on the legal powers. Also, police duties, include the tasks of managing organizational units within the Ministry (Law on Police, 2016, art. 30). 
Article 31 of the same law stipulates that „The Police shall perform police duties with the aim and in such a manner as to provide everyone with equal protection of the security, rights, and freedoms, by implementing the law and the constitutional principle of rule of law," and Article 32 regulates the principles of policing, which include " professionalism, depoliticization, cooperation, costeffectiveness and efficiency, the legality of work and proportionality in the use of police powers, as well as other principles regulating the activities of public administration authorities, and civil servants, and the procedure in administrative matters" (Law on Police, 2016).

When performing police duties, the Police shall abide by "the established and achieved standards of police procedure taking into consideration the internationally accepted standards of procedure relating to the duty to serve the citizens and the community; the response to the citizens' needs and expectations; compliance with legality and combating illegality; the exercise of human and minority rights and freedoms; non-discrimination in the performance of police tasks; proportionality in the use of means of coercion; prohibition of torture and inhuman or degrading treatment; provision of assistance to disaster victims; upholding the professional conduct and integrity; the duty to protect data secrecy; the duty to disobey unlawful orders and to report corruption" (Law on Police, 2016, art. 33).

In performing police affairs, police officers have certain duties and rights, as shown in the table below.

Table 3. Duties and rights of police officers in policing

\begin{tabular}{|c|c|c|c|}
\hline No. & $\begin{array}{c}\text { Duties and rights } \\
\text { of police officers }\end{array}$ & $\begin{array}{c}\text { Article of } \\
\text { the Law }\end{array}$ & Explanation \\
\hline 1 & $\begin{array}{c}\text { Official weapons } \\
\text { and means of } \\
\text { coercion }\end{array}$ & Article 36 & $\begin{array}{c}\text { A police officer in the status of the authorized } \\
\text { officer shall have the obligation and the right to } \\
\text { carry official firearms and ammunition. } \\
\text { Types of firearms and ammunition, as well as } \\
\text { means of coercion, namely equipment used } \\
\text { by police officers in the status of authorized } \\
\text { officers, shall be prescribed by the Government }\end{array}$ \\
\hline
\end{tabular}




\begin{tabular}{|c|c|c|c|}
\hline No. & $\begin{array}{l}\text { Duties and rights } \\
\text { of police officers }\end{array}$ & $\begin{array}{c}\text { Article of } \\
\text { the Law }\end{array}$ & Explanation \\
\hline 2 & $\begin{array}{l}\text { Official badge and } \\
\text { ID card of police } \\
\text { officers }\end{array}$ & Article 37 & $\begin{array}{l}\text { The Ministry shall issue an official badge and } \\
\text { official ID card to police officers } \\
\text { A police officer in the status of the authorized } \\
\text { officer shall be issued an official badge with } \\
\text { an official ID card, serving the purpose of } \\
\text { identification and proving the capacity of the } \\
\text { police officer during the performance of police } \\
\text { duties or exercise of police powers. } \\
\text { A police officer on special duty shall be issued } \\
\text { an official ID card, serving the purpose of } \\
\text { identification and proving the capacity of the } \\
\text { police officer during the performance of tasks } \\
\text { that are directly related to policing. }\end{array}$ \\
\hline 3 & $\begin{array}{l}\text { Uniform and } \\
\text { insignia of police } \\
\text { officers }\end{array}$ & Article 39 & $\begin{array}{l}\text { A police officer in the status of the authorized } \\
\text { officer shall be assigned a uniform, insignia, } \\
\text { and other prescribed equipment } \\
\text { The parts, appearance, and wearing of the } \\
\text { uniform, uniform insignia, and other equipment } \\
\text { for police officers shall be prescribed by the } \\
\text { Government. }\end{array}$ \\
\hline 4 & $\begin{array}{c}\text { Duty to keep } \\
\text { confidential data }\end{array}$ & Article 40 & $\begin{array}{l}\text { The Police officer shall keep confidential the } \\
\text { data acquired while performing policing duties } \\
\text { or related thereto, in accordance with the law. }\end{array}$ \\
\hline 5 & $\begin{array}{l}\text { Duties of police } \\
\text { officers outside } \\
\text { working hours }\end{array}$ & Article 42 & $\begin{array}{l}\text { Police officers in the status of authorized } \\
\text { officers shall perform police duties and exercise } \\
\text { police powers also outside the working hours. }\end{array}$ \\
\hline 6 & $\begin{array}{l}\text { Duties of police } \\
\quad \text { officers in } \\
\text { international police } \\
\text { cooperation }\end{array}$ & Article 44 & $\begin{array}{l}\text { 22Unless otherwise stipulated by an } \\
\text { international agreement, while performing } \\
\text { police tasks abroad, police officers may } \\
\text { exercise the powers and use the means } \\
\text { envisaged by an international agreement } \\
\text { underpinning the cooperation. }\end{array}$ \\
\hline 7 & $\begin{array}{l}\text { Code of Police } \\
\text { Ethics }\end{array}$ & Article 45 & $\begin{array}{c}\text { A police officer shall perform police duties in } \\
\text { accordance with the law, other regulations, and } \\
\text { rules of the profession and compliance with the } \\
\text { provisions of the Code of Police Ethics. }\end{array}$ \\
\hline 8 & $\begin{array}{l}\text { Conduct and } \\
\text { interpersonal } \\
\text { relations }\end{array}$ & Article 46 & $\begin{array}{l}\text { A police officer and other employees shall, } \\
\text { on and off duty behave in a manner that does } \\
\text { not bring discredit to the Ministry and other } \\
\text { employees in the Ministry. }\end{array}$ \\
\hline
\end{tabular}

Source: Law on Police, 2016, art. 36-46. 
In this part, it is important to mention two rulebooks - the Rulebook on the manner of performing individual police work and the Rulebook on police powers.

Rulebook on the manner of performing individual police work regulates in more detail the manner of performing individual police duties determined by the Law on Police and other laws. According to Article 2 of this Rulebook „In performing police work, the police shall apply the Police Intelligence Model, which is a way of managing police work based on criminal intelligence (strategic and operational assessments of public safety, a profile of security problem, security profile of persons of interest, and other analytical products) which are the basis for making decisions in performing police duties" (Rulebook on the manner of performing individual police work, 2018).

The Rulebook stipulates that the following is achieved through police work: 1) crime prevention and improvement of security in the community, detection and crime solving; 2) providing evidence, their analysis, criminal forensic expertise using modern forensic methods and records and detection of property derived from a criminal offense; 3 ) detection and solving of misdemeanors and commercial offenses; 4) detection and arrest of perpetrators of criminal offenses, misdemeanors and other wanted and their apprehension by the competent authorities; 5) maintaining public order and peace, preventing violence at sports events, providing assistance in enforcement in accordance with the law; 6) regulation, control, provision of assistance and supervision in road traffic and other activities from the regulations on traffic safety; 7) safeguardning of certain public gatherings, persons, facilities and spaces; 8) safeguarding of certain persons and objects; 9) control of the state border, activities related to the movement and stay of foreigners, activities of asylum, cross-border crime, and regular migration and readmission; 10) performing tasks determined by regulations on weapons, private security and detective activity; 11) ssafeguarding the Ministry; 12) performing other police tasks and duties determined by law and by-laws of the Ministry issued on the basis of authorizations from the law.

The Rulebook on Police Powers "prescribes the manner of application of police powers, the manner of conduct of police officers towards apprehended and detained persons, the manner of conduct of police officers in the application of criminal-tactical and forensic methods and means, closer manner of proceeding when receiving found items, manner of use of means of coercion, manner of assessment of justification and regularity of use of means of coercion and control of the use of means of coercion" (Rulebook on police powers, 2019, art. 1).

Furthermore, according to the provisions of the Rulebook, "before exercising the police authority, the police officer will in each specific case assess 
whether they can safely exercise the police authority, without endangering their own and the safety of others." During the exercise of police authority, a police officer who exercises police authority, as well as a police officer who is present at the place of performance of police authority, but does not directly apply it, must always be ready to repel any attack from himself or another person or to prevent possible self-harm. or the escape of a person towards whom a police power is exercised " (Rulebook on police powers, 2019, art. 3).

The same article stipulates that "if a police officer assesses that he/she cannot safely exercise police authority, he/she shall immediately inform the organizational unit responsible for the permanent duty of his / her organizational unit or immediate supervisor and request the necessary assistance to perform his / her official task". while Article 4 stipulates that "when exercising police duties, a police officer shall prepare a report on the exercised police duty" (Rulebook on police powers, 2019, art. 3-4).

\section{Criminal Procedure, Misdemeanor, and Administrative Duties of the Police During the Prevention, Detection, and Solving of Criminal Offenses and other Crimes}

The criminal procedure activity of the police includes a group of various "criminalistic, criminal procedure and related activities of the police in the prevention and suppression of crime, the performance of which perform a special part of their activities and perform their criminal procedure function" (Miletić, 2004, p. 52).

According to Jovanović (2016), "public confidence in the work and efficiency of the police largely depends on the success of the police in the prevention of criminal acts and in detecting criminal acts with an unknown perpetrator and solving them. More precisely, with this activity, the police contribute to the function of criminal prosecution and the judicial function in criminal matters. This is done through police (operational) work, collecting data and evidence, which is obtained through criminal work and the application of police powers. Namely, these powers are not only criminal procedural, but also police authority, and sometimes basically the same action occurs as procedural, sometimes as misdemeanor procedure, and sometimes as administrative "(p. 142).

Other authors have a similar attitude. Namely, according to Jugović (2013), "since these powers, as well as the entire activity, is determined by a special legal regime, indirectly, through the application of police powers stipulated by the Law on Police which have the character of administrative actions, and only when they have this character, the administrative activity also occurs - therefore, insignificantly and exceptionally" (p. 67). 


\section{Conclusion}

The new concept of combating crime is based on the preventive activities of the police and the judiciary. In this sense, police affairs can be approached from different aspects. The primary role of the police is in the criminal and misdemeanor procedure, but, as concluded in the text of this paper, the administrative activities of the police in preventing, detecting, and solving criminal acts, misdemeanors, and other crimes are also very important.

In this sense, the paper deals with issues that significantly helped to analyze the main topic of this research paper in the best possible way. This paper analyzes issues related to the affairs of the Ministry of Internal Affairs, organization and competence of the police, principles of operation of state administrative bodies, police affairs, and criminal and misdemeanor procedure, as well as administrative activities of the police in preventing, detecting and solving crimes and other offenses. The primary legal texts that were consulted were the Law on Police and the Law on State Administration, in addition to consulting two important Rulebooks in this area - the Rulebook on police powers and the Rulebook on the manner of performing individual police duties.

\section{Bulatović Petar}

Master pravnik, Beogradska akademija poslovnih i umetničkih strukovnih studija, Srbija

\section{OBAVLJANJE POLICIJSKIH POSLOVA U KONTEKSTU NAČELA KOJIMA JE UREĐENO DELOVANJE ORGANA DRŽAVNE UPRAVE}

REZIME: Policijski poslovi su deo unutrašnjih poslova koje obavlja Policija, primenom policijskih ovlašćenja, mera i radnji. Nov koncept suprotstavljanja kriminalu zasnovan je na preventivnim aktivnostima policije i pravosuđa. $U$ tom smislu, aktivnosti policije mogu da se analiziraju sa različitih aspekata. Primarna uloga policije jeste krivičnoprocesna i prekršajna, ali, kao što se i u samom tekstu rada moglo zaključiti, vrlo su 
značajne i upravne aktivnosti policije prilikom sprečavanja, otkrivanja i rasvetljavanja krivičnih dela, prekršaja i drugih delikata. U tom smislu, rad se bavio pitanjima koja su značajno pomogla da se osnovna tema rada analizira na što bolji način. U radu su analizirana pitanja u vezi sa poslovima Ministarstva unutrašnjih poslova, organizacijom i nadležnošću policije, načelima delovanja organa državne uprave, policijskim poslovima, te krivičnoprocesnim, prekršajnim i upravnim aktivnostima policije prilikom sprečavanja, otkrivanja i rasvetljavanja krivičnih dela i drugih delikata. Primarni zakonski tekstovi koji su pritom konsultovani su Zakon o policiji i Zakon o državnoj upravi, uz konsultovanje i dva značajna pravilnika u ovoj oblasti - Pravilnika o policijskim ovlašćenjima i Pravilnika o načinu obavljanja pojedinačnih policijskih poslova.

Ključne reči: policijski poslovi, organi državne uprave, načela, krivičnoprocesne aktivnosti policije, upravne aktivnosti policije

\section{References}

1. Jovanović, Z. (2016). Upravna delatnost policije i značaj reforme državne uprave u Republici Srbiji [Administrative activity of the police and the importance of public administration reform in the Republic of Serbia]. Zbornik radova Pravnog fakulteta u Nišu, 55 (73), pp. 137-151

2. Jugović, S. (2009). Mere ciljane potrage [Measures of targeted search]. NBP - Žurnal za kriminalistiku i pravo, 14 (3), pp. 191-200

3. Jugović, S. (2013). Upravna funkcija policije [Administrative function of the police]. Beograd: Kriminalističko-policijska akademija

4. Kulić, M. (2017). Upravno pravo-opšti deo [Administrative law-general part]. Novi Sad: Pravnifakultet za privredu i pravosuđe u Novom Sadu

5. Miletić, S. (2004). Pojmovnik policijskog prava [Glossary of police law]. Beograd: Službeni glasnik

6. Milić, N. (2010). Aktuelni problemi organizacije i funkcionisanja policijske ispostave [Current problems of organization and functioning of the police station]. In: Nikač, Ž. (ed.) Pravo i forenzika u kriminalistici [Law and forensics in criminology] (pp. 115-128). Beograd: Kriminalističkopolicijska akademija

7. Milidragović, D. \& Milić, N. (2019). Rezultati i problemi policije opšte nadležnosti u suzbijanju kriminala [Results and problems of the police of general competence in the suppression of crime]. NBP-Žurnal za kriminalistiku i pravo, 24 (1), pp. 63-81. DOI: 10.5937/nabepo24-19545 
8. Pravilnik o policijskim ovlašćenjima [Rulebook on police powers]. Službeni glasnik RS, no. 41/19

9. Pravilnik o načinu obavljanja pojedinačnih policijskih poslova [Rulebook on the manner of performing individual police work]. Službeni glasnik $R S$, no. $63 / 18$ and $72 / 18$

10. Simić, B. \& Nikač, Ž. (2009). Razvoj policijske organizacije od tradicionalne ka savremenoj u funkciji suzbijanja kriminaliteta [Development of the police organization from traditional to modern in the function of crime suppression]. NBP - Žurnal za kriminalistiku i pravo, 14 (3), pp. $117-131$

11. Vasiljević, D. (2012). Disreciona ovlašćenja policije [Discretionary powers of the police]. NBP-Žurnal za kriminalistiku i pravo, 17 (1), pp. $19-35$

12. Zakon o policiji [Police Law]. Službeni glasnik $R S$, no. 6/16, 24/18 and $87 / 18$

13. Zakon o državnoj upravi [Law on State Administration]. Službeni glasnik $R S$, no. 79/05, 101/07, 95/10, 9/14, 47/18 and 30/18 - other law

14. Zakon o ministarstvima [Law on ministries]. Službeni glasnik $R S$, no. $128 / 20$ 